\title{
Particle processing on the gill plicae of the oyster Crassostrea gigas: fine-scale mucocyte distribution and functional correlates
}

\author{
Peter G. Beninger*, Rozenn Cannuel, Samuel Jaunet
}

Laboratoire de Biologie marine, Faculté des Sciences et Techniques, 2, rue de la Houssinière, 44322 Nantes Cedex 3, France

\begin{abstract}
In order to resolve outstanding problems in the understanding of mechanisms of particle processing in the oyster gill, the technique of mucocyte mapping was used to quantify mucocyte types and fine-scale distributions on the frontal ciliated tracts of the ordinary filaments comprising the gill plicae. The frontal tracts were divided into 1 frontal median tract (FMT) and 2 frontal lateral tracts (FLT) per filament, based on relative cilia lengths. Mucocyte counts within each tract were performed on periodic acid Schiff (PAS)-alcian blue-stained histological sections under oil immersion, and densities were recorded per linear $\mu \mathrm{m}(\mathrm{l} \mu \mathrm{m})$ of tract width, after evaluation of artefactual shrinkage for exact dimensions of tracts. Total mucocyte volumes were obtained using mean mucocyte volumes. Two types of mucocytes were most frequently observed: acid mucopolysaccharide (AMPS) containing mucocytes, and mixed (acid + neutral) mucopolysaccharide (MMPS) containing mucocytes. Neutral mucopolysaccharide (NMPS) containing mucocytes were rare. The apical filaments contained over twice the mucocyte densities and total mucocyte volumes, compared to the lateral filaments of the plicae ( $\mathrm{p} \leq 0.001)$, indicating that the apical filaments are the principal particle processing site of the plicae. The lateral filaments may accomplish functions more related to the establishment of the plicae and ensuing consequences (hydrodynamic particle capture, physical separation of the dorsal and ventral gill particle groove functions, and enlargement of filtering area). On the apical filaments, the FMT showed much greater AMPS containing mucocyte densities and total mucocyte volumes, compared to the FLT. This, together with the respective cilia length differences, indicates that the FMT is the principal particle transport tract. Such a specialization was not observed on the lateral filaments of the plicae, again supporting the conclusion that the apical filaments are the active site of particle processing on the plicae. FLT appear to be uninvolved in particle transport, and probably participate in the establishment and maintenance of the dorsalward current flow in the pallial cavity.
\end{abstract}

KEY WORDS: Crassostrea gigas $\cdot$ Oyster $\cdot$ Gill $\cdot$ Ciliated tracts $\cdot$ Mucocytes $\cdot$ Feeding

\section{INTRODUCTION}

Over the past $15 \mathrm{yr}$, considerable progress has been made in the understanding of benthic suspensionfeeder particle processing mechanisms (reviewed in Riisgård \& Larsen 2000, 2001). In particular, a sustained effort has resulted in an enhanced understanding of these mechanisms in suspension-feeding bivalves, in 3 of the 4 major processing systems: (1) homorhabdic filibranch (Beninger et al. 1991, 1993,
1995, Nielsen et al. 1993, Ward et al. 1993, Riisgård et al. 1996, Beninger et al. 1997a, Silverman et al. 1999), (2) heterorhabdic filibranch (Beninger et al. 1992, 1993, 2004, Beninger \& St-Jean 1997a,b, Beninger \& Decottignies 2005), and (3) eulamellibranch (Ward et al. 1993, Silverman et al. 1996, Beninger et al. 1997b). The pseudolamellibranch is the 4 th and most enigmatic of these systems, despite several energetic research efforts (Ward et al. 1993, 1994, 1998). The pseudolamellibranch system is found in the commer- 

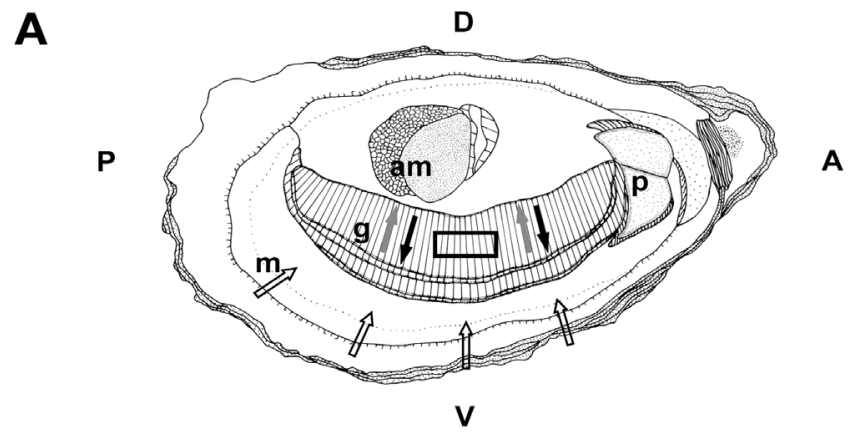

B
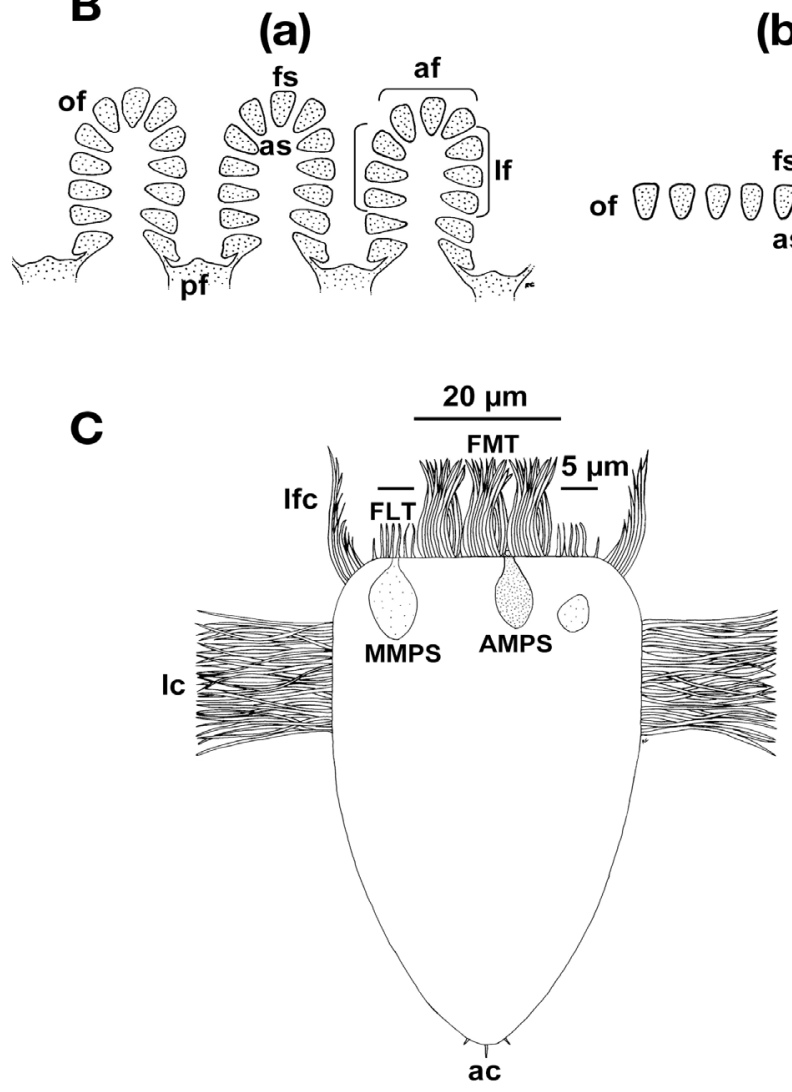

Fig. 1. (A) Crassostrea gigas, right valve and mantle removed, showing gill site for mucocyte counts (rectangle); grey arrows: dorsal particle transport on the principal filaments of gill plicae; black arrows: ventral particle transport on the ordinary filaments of gill plicae; empty arrows: inhalant water currents. A: anterior, D: dorsal, P: posterior, V: ventral (organ orientations), am: adductor muscle, g: gills, m: mantle, p: palps. Redrawn from Cognie (2001). (B) Diagrammatic comparison of a heterorhabdic (including $C$. gigas pseudolamellibranch) gill and a homorhabdic gill (e.g. Mytilus spp.). (a) C. gigas transverse section passing through a row of ostia. (b) Transverse section of a homorhabdic filibranch gill. of: ordinary filament, pf: principal filament, fs: frontal surface, as: abfrontal surface, af: apical filament, lf: lateral filament. (C) Diagram of $C$. gigas ordinary filament transverse section and location of the different ciliated tracts. ac: abfrontal cilia, FLT: frontal lateral tract simple (fine) cilia, FMT: frontal median tract composite (coarse) cilia, lc: lateral cilia, lfc: composite latero-frontal cilia, MMPS: mixed mucopoly-saccharide containing mucocyte, AMPS: acid mucopolysaccharide containing mucocyte cially important family Ostreidae, and is characterized by a deeply plicate, heterorhabdic gill (i.e. composed of 2 filament types: the concave principal filaments at the bases of the plicae, themselves composed of 10 to 12 convex ordinary filaments, Fig. 1B-a). The differences between a heterorhabdic gill (including the pseudolamellibranch gill) and a homorhabdic gill are shown in Fig. 1B.

Bi-directional particle transport has been firmly established on the pseudolamellibranch gill, with particles initially accepted being sent dorsally via the principal filaments, and particles either initially rejected or those too large to enter the principal filament openings sent ventrally to the ventral ciliated groove as shown in Fig. 1A (Ward et al. 1994, 1998, Cognie et al. 2003). The sites of selection are also relatively well documented in the pseudolamellibranch system (Ward et al. 1998, Cognie et al. 2003), as well as the mechanism of pseudofeces evacuation from the pallial cavity (Beninger \& Veniot 1999). However, several fundamental questions remain concerning the functioning of this system: (1) Contrary to the situation in the homorhabdic gills (Silverman et al. 1996, 1999), the capture mechanism is unknown. Although latero-frontal cirri (LFC) are present, they are much reduced compared to those of the homorhabdic gills, and conform to the composite rather than the compound type (Beninger \& Veniot 1999, Beninger et al. 1999, P. G. Beninger unpubl. data). The gill is heterorhabdic, so that in principle, particle capture could be accomplished without LFC, as in the Pectinidae, presumably through hydrodynamic capture (Owen \& McCrae 1976). The first unanswered question is therefore: Are particles captured by the small loosely grouped LFC, or by hydrodynamic means, or both? (2) The oyster gill is unique in that it is both heterorhabdic, and at the same time it possesses multiple ciliated tracts on the ordinary filaments (Fig. 1C). Two frontal lateral tracts (FLT), with 'fine' (simple) cilia, and a frontal median tract (FMT), with 'coarse' (composite) cilia, are found on these frontal surfaces (Atkins 1937a,b, 1938, Ribelin \& Collier 1977, P. G. Beninger unpubl. data). From early direct observations of dissected material, Atkins $(1937 a, b)$ deduced that the FMT cilia beat ventrally, while the FLT cilia beat dorsally; this was later supported by Ribelin and Collier (1977), based on the prevalent angles of the cilia as fixed and observed under scanning electron 
microscopy (SEM). With the well-documented observation that particles on the plicae are always transported to the ventral particle groove (Ward et al. 1994 and Fig. 1A), and the affirmation of the ventral particle groove as an initial rejection site (Ward et al. 1998), the question of the roles of the frontal tracts obviously arises. If bi-directional transport on the ordinary filaments does not occur, what does the presence of a bi-directional beat signify?

Precise knowledge of processing events on the oyster gill ordinary filaments is lacking, due to the inability to distinguish between the 3 frontal tracts other than through optical or electron microscopy on fixed and stained gill fragments (Ribelin \& Collier 1977, Beninger 2000). Information concerning the function of these 3 tracts must therefore be obtained by indirect methods.

Mucocyte mapping has been shown to be a useful technique to enhance understanding of bivalve particle processing mechanisms (Beninger et al. 1993, 1997b, 2003, Beninger \& Dufour 1996, Beninger \& St-Jean $1997 \mathrm{a}, \mathrm{b})$. It is possible to relate the type of underlying mucus secretion to the type of transport (mucociliary or hydrodynamic), the type of surface, and the direction of particle transport relative to particle flow (Beninger \& St-Jean 1997a). The 3 oyster ordinary filament frontal ciliated tracts are especially interesting in this regard, because a difference in the underlying mucus secretion types would indicate that the FMT and FLT perform different functions; it would also shed light on the nature of these functions. Mucocyte distribution on such a fine scale has not been attempted to date. The present study therefore uses mucocyte mapping to elucidate the particle processing roles of the ordinary filament frontal ciliated tracts in the pseudolamellibranch system of the Pacific oyster Crassostrea gigas.

\section{MATERIALS AND METHODS}

Specimen sampling and histological processing. Fourteen adult Crassostrea gigas (7.1 to $9.2 \mathrm{~cm}$, longest axis) were sampled from the Baie de Bourgneuf $\left(47^{\circ} 5^{\prime} \mathrm{S}, 2^{\circ} 5^{\prime} \mathrm{W}\right)$, and the gills were immediately dissected out and fixed in aqueous Bouin's solution in the field. After $48 \mathrm{~h}$ fixation, they were rinsed under flowing water for $24 \mathrm{~h}$, dehydrated, and embedded in paraffin. Transverse $5 \mu \mathrm{m}$ sections were made in the mid-region of the gill (Fig. 1A) for each specimen, and stained using the following alcian blue-periodic acidSchiff (PAS) protocol, as perfected in initial trials: $1 \%$ alcian blue pH 2.5 (2 min), 1\% periodic acid $(2 \mathrm{~min})$, Schiff reagent (15 min) (Merck, activity varies markedly among suppliers), and sodium metabisulfite $(3 \times 3 \mathrm{~min})$. Controls were subjected to diastase digestion prior to staining. The resulting mucocyte secretion colours were standardized using the Pantone ${ }^{\circledR}$ colour coding system (Beninger et al. 1993, 1997b, 2003, Beninger \& Dufour 1996, Beninger \& St-Jean 1997a,b).

Estimation of tissue shrinkage and filament width homogeneity. In order to estimate tissue, and hence ciliated tracts shrinkage, due to fixation and histological processing, 30 apical filament widths for each of 10 adult individuals were measured on both fresh gill tissue and sections processed according to the protocol outlined above (600 measurements in total). This step allowed the establishment of a width correction factor which could be applied to the counted sections, in order to determine the true (i.e. living) widths of the frontal ciliated tracts. It also allowed the estimation of filament width homogeneity within and between individuals.

Mucocyte counts. Mucocyte counts were performed on 30 haphazardly chosen filaments per plical location (apical or lateral filament, Fig. 1B), for each of the 14 oysters, in order to establish their relative abundances on the component filaments of the plicae. This approach was designed to determine whether all filaments of a plica were equally important in particle transport (relative filament activity). Only mucocytes whose openings to the frontal surface could be visually ascertained were typed and counted.

In addition, mucocyte fine distribution was established on the frontal surface of gill ordinary filaments (FMT or FLT, Fig. 1C), after ascertaining that filament width was homogeneous within and between individuals (see above). Each filament section was divided into 3 counting zones, corresponding to the 2 FLT and the 1 FMT; these were easily distinguishable under oil immersion due to the greater length of the cilia of the FMT. It was possible to quantify the relative numbers and types of mucocytes which discharged their secretions onto each of the 3 frontal ciliated tracts (Fig. 1C). The tract widths were uniform: $5 \mu \mathrm{m}$ for each of the FLT, and $20 \mu \mathrm{m}$ for the FMT, as previously reported for Crassostrea virginica (Ribelin \& Collier 1977). Mucocyte counts were performed at $1000 \times$ under oil immersion, using a digital camera and computer screen. Images were stored using LUCIA $G^{\circledR}$ software, pending counts.

In order to evaluate the instantaneous total volumes of mucus contained in mucocytes, 30 mucocytes of each type were measured and converted to volumes. All mucocytes were slightly bent, and after straightening were ellipsoid-shaped; half-length major $(x)$ and half-length minor $(y)$ axes were measured, and the corresponding volumes $(V)$ were calculated $\left(V=4 / 3 \pi x y^{2}\right)$. Mean volumes were thus calculated for each mucocyte type; these values were multiplied by mucocyte number to obtain the total mucocyte volume. These values were underestimations, since the maximum long and short axes may not always have been in the plane of 
section. This underestimation should be consistent for all mucocyte types, given the sample size for this determination.

Hypotheses and statistical analyses. The following 2 sets of hypotheses were formulated. (1) $\mathrm{H}_{0}$ : There will be no significant difference in mucocyte types, densities and total volumes between apical and lateral filaments of a plica. $\mathrm{H}_{1}$ : There will be consistent, significant difference in mucocyte types, densities and total volumes between apical and lateral filaments of a plica. The conclusion here would be that the filaments with the largest densities and total volumes of mucocytes are more active in particle processing than those with smaller numbers and total volumes of mucocytes. (2) $\mathrm{H}_{0}$ : There will be no significant difference in mucocyte types, densities and total volumes between frontal ciliated tracts of the ordinary filaments. $\mathrm{H}_{1}$ : There will be significant difference in mucocyte types, densities and total volumes between the frontal ciliated tracts of the ordinary filaments. The conclusion here would be that different tracts perform different roles or participate to different degrees in particle processing on the ordinary filaments. The interpretation of this finding could be carried further, based on cilia and mucus types dominant on the particular tracts.

A 2-tailed Student's $t$-test was performed when the mucocyte distribution data was normal and variances homogeneous, and a Mann-Whitney rank sum test was performed when data were nonnormal despite all transformations, with $\alpha=0.05$. A 1 -way parametric ANOVA was performed on the normally distributed and homoscedastic shrinkage data, with $\alpha=0.05$.

\section{RESULTS}

\section{Tissue shrinkage}

Intra-individual differences in apical filament widths were small (coefficient of variation $=8.6 \%$ ), and no significant inter-individual differences in apical filaments widths were found $(\mathrm{p}=0.091$, general mean $\pm 95 \%$ confidence interval $[\mathrm{CI}]=53.3 \pm 0.5 \mu \mathrm{m}$, range 51.5 to $54.9 \mu \mathrm{m}$ ) in fresh gill tissue, allowing standardization of mucocyte counts within the $30 \mu \mathrm{m}$ wide (post-histological processing) frontal surface. General mean and standard deviation of shrinkage after fixation and histological processing was $32 \pm 2.3 \%$.

\section{Mucocyte types}

In longitudinal section, all Crassostrea gigas mucocytes were oval-shaped, and hence could be represented as ellipsoids in 3 dimensions (Table 1, Fig. 1C).
Table 1. Crassostrea gigas. Secretion type, visual and Pantone ${ }^{\circledR}$ standard colours, and mean volumes of stained mucocytes in C. gigas gill. AMPS $=$ acid mucopolysaccharides; MMPS $=$ mixed mucopolysaccharides; NMPS = neutral mucopolysaccharides

\begin{tabular}{|c|c|c|c|}
\hline $\begin{array}{l}\text { Mucocyte } \\
\text { secretion } \\
\text { type }\end{array}$ & $\begin{array}{l}\text { Visual } \\
\text { colour }\end{array}$ & $\begin{array}{l}\text { Pantone }^{\circledR} \\
\text { standard } \\
\text { colours }\end{array}$ & $\begin{array}{l}\text { Mean ellip- } \\
\text { soid volumes } \\
\qquad\left(\mu^{3}\right)\end{array}$ \\
\hline AMPS & Sky blue & $2935 c$ & 174.8 \\
\hline MMPS & Violet to indigo & $2385 c^{*}, 2573 c$ & 315.2 \\
\hline NMPS (rare) & Intense pink & $2375 \mathrm{c}$ & - \\
\hline
\end{tabular}

All mucocytes were situated in the ciliated epithelium, and no sub-epithelial glands were observed. Mixed mucopolysaccharide (MMPS) containing mucocytes were significantly larger than acid mucopolysaccharide (AMPS) containing mucocytes in all sections examined, with mean volumes $( \pm 95 \% \mathrm{CI})$ of 315.2 $( \pm 61.2) \mu^{3}$ and $174.8( \pm 26.0) \mu^{3}$, respectively $(\mathrm{p} \leq 0.001)$.

\section{Relative mucocyte density on the component filaments}

A significant difference was observed in total mucocyte densities between the lateral filaments and the

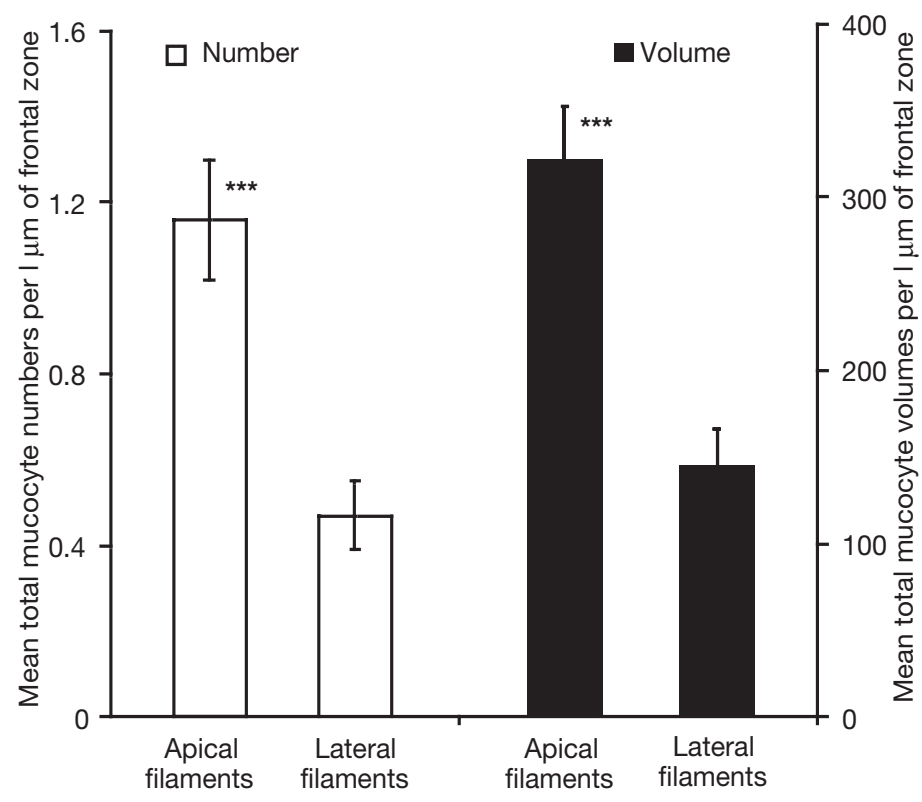

Fig. 2. Crassostrea gigas. Total cumulative (AMPS [acid mucopolysaccharide] + MMPS [mixed mucopolysaccharide]) mucocyte numbers and total cumulative (AMPS + MMPS) mucocyte volumes $\left(\mu \mathrm{m}^{3}\right)$ per linear $\mu \mathrm{m}(\mathrm{l} \mu \mathrm{m})$ of frontal surface of apical and lateral filaments of plicae. Means $\pm 95 \%$ CI (vertical bars). ${ }^{* * *}$ Values significantly different at $\mathrm{p} \leq 0.001$ 
apical filaments of the plicae $(p \leq 0.001)$. The apical filaments contained the greatest densities of mucocytes, with much smaller densities on the lateral filaments (Fig. 2). In addition, each apical filament presented more than twice the volume of mucus (AMPS + MMPS) compared to the mean value for the lateral filaments ( $\mathrm{p} \leq 0.001$, Fig. 2). Moreover, MMPS containing mucocytes were more abundant, and formed a greater total volume than the AMPS containing mucocytes in all cases ( $\mathrm{p} \leq 0.001$, Fig. 3B,C).
Table 2. Crassostrea gigas. Total potential mucus secretion volume of the frontal median tract (FMT) and the 2 front lateral tracts (FLT) of apical and lateral filaments $\left(\mu \mathrm{m}^{3}\right)$. AMPS $=$ acid mucopolysaccharides; MMPS = mixed mucopolysaccharides

\begin{tabular}{|lccrr|}
\hline & \multirow{2}{*}{ Apical filament } & \multicolumn{2}{c|}{ Lateral filament } \\
& FMT & FLT & FMT & FLT \\
\hline AMPS & 1386.20 & 312.20 & 124.80 & 50.00 \\
MMPS & 4616.00 & 3310.02 & 2409.40 & 1756.30 \\
AMPS + MMPS & 6002.20 & 3622.22 & 2534.20 & 1806.30 \\
$\frac{\text { AMPS } \times 100}{\text { AMPS + MMPS }}$ & $23 \%$ & $9 \%$ & $5 \%$ & $3 \%$ \\
\hline
\end{tabular}

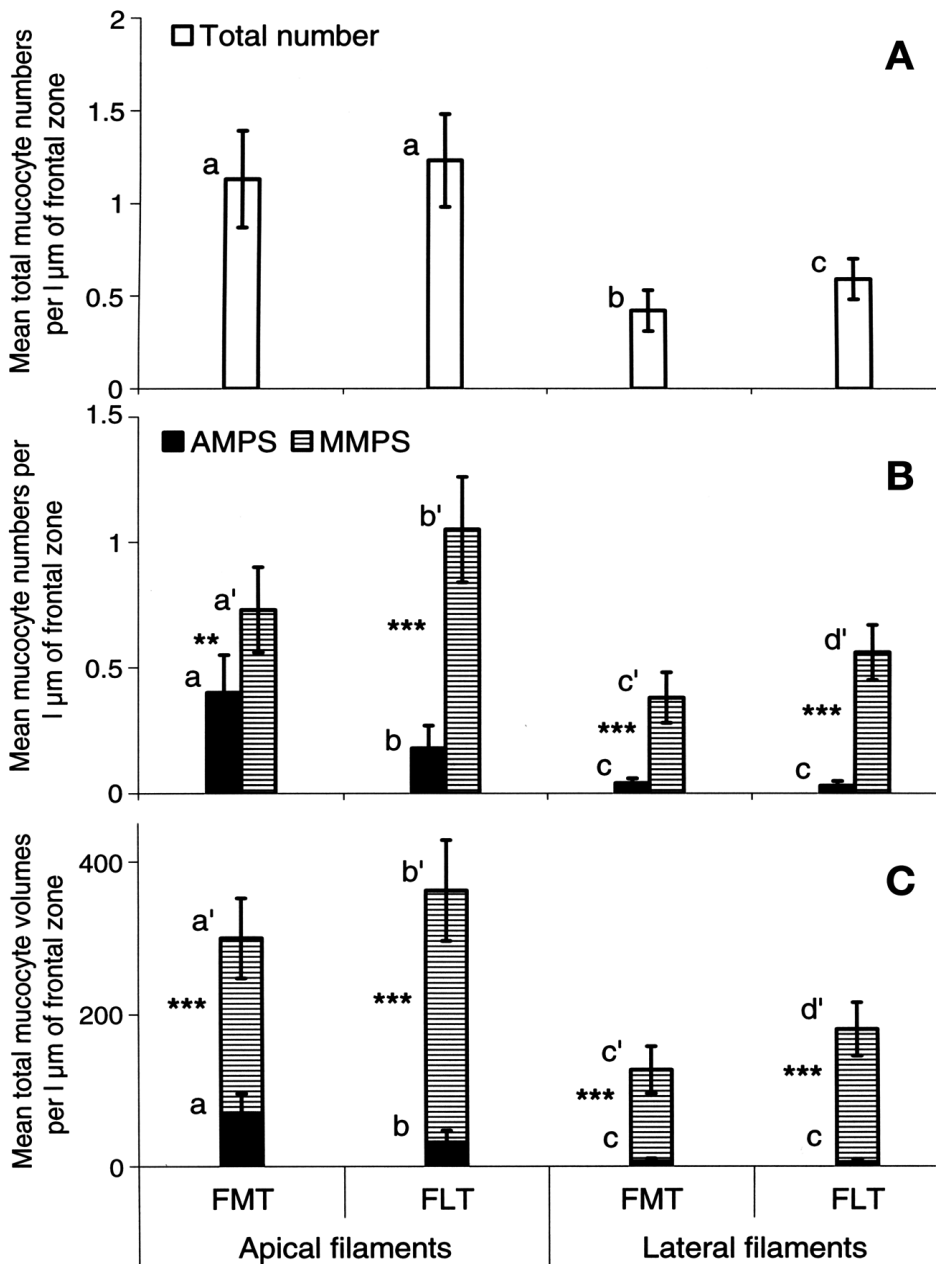

Fig. 3. Crassostrea gigas. (A) Total cumulative (AMPS [acid mucopolysaccharide] + MMPS [mixed mucopolysaccharide]) mucocyte numbers per linear $\mu \mathrm{m}(\mathrm{l} \mu \mathrm{m})$ of frontal surface in frontal median tract (FMT) and front lateral tract (FLT) of apical and lateral filaments of plicae. (B) AMPS and MMPS containing mucocyte numbers per $1 \mu \mathrm{m}$ of frontal surface in FMT and FLT of apical and lateral filaments of plicae. (C) Total AMPS and MMPS containing mucocyte volumes $\left(\mu \mathrm{m}^{3}\right.$ per $1 \mu \mathrm{m}$ of frontal surface) in FMT and FLT of apical and lateral filaments of plicae. Means $\pm 95 \%$ CI (vertical bars). Values with the same letter do not differ significantly (p-values in text). ***Values of AMPS and MMPS significantly different at $\mathrm{p} \leq 0.001, * *$ values of AMPS and MMPS significantly different at $\mathrm{p} \leq 0.01$

\section{Mucocyte distribution within the apical filaments}

No significant difference was observed either in total mucocyte densities between the FMT and the FLT on the apical filaments (Fig. 3A, $p=0.591$ ), or in the cumulative (AMPS + MMPS) total mucocyte volumes (Fig. $3 \mathrm{C}, \mathrm{p}=0.224$ ). However, within mucocyte types, significant differences in mucocyte densities and total mucocyte volumes were found, depending on the location in the apical filaments. In particular, the FMT contained a more than 2-fold larger total volume of AMPS containing mucocytes, compared to the FLT ( $p=0.022$, Fig. $3 C$ ). AMPS represented $23 \%$ of the potential total volume for the FMT, compared to $9 \%$ for the combined FLT, a difference of over 2.5-fold (Table 2). Significant differences were also observed in the densities and the total volumes of MMPS containing mucocytes, between the FMT and the FLT $(p=0.027)$.

\section{Mucocyte distribution within the lateral filaments}

The FMT of the lateral filaments showed significantly lower cumulative densities of mucocytes compared to the FLT ( $p=0.045$, Fig. 3A). This difference was due to significant differences in MMPS containing mucocyte densities (Fig. 3B, $p=0.007$ ). The total volume of MMPS was also significantly lower on the FLT (Fig. 3C, p = 0.007). No significant difference was observed in the AMPS containing mucocyte densities and total mucocyte volumes between the FMT and FLT (Fig. 3B,C, p = 0.564). AMPS represented 5 and $3 \%$ of the cumulative total mucocyte volume for the FMT and the combined FLT, respectively (Table 2, Fig. 3C). 


\section{DISCUSSION}

\section{Mucocyte types and relative particle processing activity of the filaments}

The present study identified 2 major types of mucocytes on the Crassostrea gigas gill: those containing AMPS and those containing MMPS. Neutral mucopolysaccharide (NMPS) containing mucocytes were rare. While the 2 major mucocyte types provide secretions of different viscosity, the mixing which occurs on the frontal surface as a result of the ciliary beat would produce a more viscous mucus on the FMT compared to the FLT. A similar study in $C$. virginica found only AMPS containing mucocytes and NMPS containing mucocytes, although the exact positions of the mucocytes on the frontal tracts was not recorded (Beninger \& Dufour 1996). The NMPS are less viscous than the MMPS, but in $C$. virginica the numbers of each type were nearly equal, with a slight dominance of AMPS. The resulting mixture would probably display a viscosity similar to that observed on the $C$. gigas frontal surface overall.

The highly significant difference in total mucocyte densities and total mucocyte volumes, between the apical and the lateral plical filaments, leads to the rejection of $\mathrm{H}_{0}(1)$, which states there are no significant differences in mucocyte types, densities and total volumes between apical and lateral filaments of a plica, and the acceptance of $\mathrm{H}_{1}(1)$, which is in favour of the apical filaments. In the natural state (as opposed to when particles are deposited directly onto dissected gills-Atkins 1937a), the apical filaments are therefore much more active in particle processing, compared to the lateral filaments. Mucocyte mapping allows this conclusion to be drawn, whereas direct video-endoscopic observations fail to yield the necessary information, due to the proximity of the pseudolamellibranch plicae to each other. This conclusion is further supported by the striking difference in the AMPS / (AMPS + MMPS) percentages: 23 (FMT) vs. $9 \%$ (combined FLT) for the apical filaments, compared to 5 and $3 \%$, respectively, for the lateral filaments (Table 2). A similar apical filament-lateral filament distributional difference was observed previously in Crassostrea virginica (Beninger \& Dufour 1996), as well as in the heterorhabdic filibranchs Chlamys varia and Placopecten magellanicus (Owen \& McCrae 1976, Beninger et al. 1993).

\section{Alternative functions of the lateral filaments}

Taken together, the results cited above strongly suggest that in the bivalve heterorhabdic gill, the apical filaments are the principal sites of particle processing on the plicae. The lateral filaments play a secondary role, and we suggest that their main function is not directly in particle transport, but in the structural formation and maintenance of the plicae and subsequent topography-dependent water currents, which are universal features of the heterorhabdic gill. The plicae themselves perform several very important functions in particle processing. The first of these functions is the strong hydrodynamic component of particle capture, as opposed to direct cirral capture of particles (Owen \& McCrae 1976, latero-frontal cirri being reduced or absent in these bivalves). A second function is the physical separation of the dorsal (initial acceptance) and ventral (rejection: heterorhabdic filibranchs; initial rejection: pseudolamellibranchs) collecting tracts on the gill (Ward et al. 1994). Finally, the plicae allow an increase of filtering and respiration surface area, while conserving overall gill dimensions. The lateral filaments of the plicae, being the ones which give rise to the plical form, may be much more useful in fulfilling these functions than they would be as direct particle processing entities.

It has been suggested that the individual gill filament is the fundamental particle processing unit in bivalves (Ward et al. 1998). The present and previous studies of the heterorhabdic gill (Beninger et al. 1993) strongly suggest that not all filaments play an equal, or even similar, role in particle processing. Furthermore, it is very likely that the filaments of the heterorhabdic gill perform cooperative functions, such as hydrodynamic capture and plical maintenance, so that they cannot wholly be considered individually from a functional standpoint.

\section{Relative mucocyte distributions on the apical filament frontal ciliated tracts}

The quantitative results of the present study are at variance with the qualitative observations of Ribelin \& Collier (1977) in Crassostrea virginica, who reported that mucocytes were generally restricted to the boundary regions between the FLT and the FMT, and were rarely observed in the fine FLT. In C. gigas, mucocytes were observed throughout the 3 frontal tracts, and in fact there is no significant difference in total density between the FMT and the FLT; however, the total mucocyte volumes were significantly different in the FMT.

The relative mucocyte densities and total mucocyte volumes on the apical filament frontal tracts, reveal a striking difference in the distribution of AMPS; leading to a rejection of $\mathrm{H}_{0}(2)$ which states that there are no significant differences in mucocyte types, densities and to- 
tal volumes between frontal ciliated tracts of the ordinary filaments, and acceptance of the corresponding $\mathrm{H}_{1}(2)$ that there are significant differences in mucocyte types, densities and total volumes between the FMT and the FLT, in favour of AMPS mucocytes on the FMT.

\section{Functional correlates: FMT}

AMPS containing mucocytes secrete the most viscous mucopolysaccharides (Grenon \& Walker 1978, Beninger \& St-Jean 1997a), thus based on the AMPS / (AMPS + MMPS) percentages it is evident that the FMT is characterized by a much more viscous secretion than are the FLT. The FMT also presents 2 other differences with respect to the FLT: the cilia are composite (P. G. Beninger unpubl. data), and they are much longer (15 vs. $5 \mu \mathrm{m}$, respectively - Veniot 2003). SEM observations of these cilia are consistent with the suggestion that they beat dorsoventrally (Ribelin \& Collier 1977), in which case this tract would be responsible for the dorsoventral particle transport observed on the oyster plicae (Atkins 1937a,b, Ward et al. 1994). As the prevailing current is ventrodorsal, this countercurrent particle transport can only be accomplished if the particles adhere closely to the ciliated epithelium. Beninger \& St-Jean (1997a) demonstrated that AMPS or ADMPS (acid-dominant mucopolysaccharides) are universally used by bivalve pallial organs in such circumstances, and the observations of the present study extend this rule to a finer scale: 1 ciliated tract out of 3 contiguous tracts, on a single frontal ciliated surface only $40 \mu \mathrm{m}$ wide (fresh gill tissue). Although clearance, selection, and endoscopic studies of oyster feeding routinely use small particle sizes ( 3 to $20 \mu \mathrm{m}$, Ward et al. 1994, 1998, Ropert \& Goulletquer 2000), their gills are exposed to a very wide range of particle sizes, including large, dominant coastal diatoms (Levinton 1982, Lakshminarayana 1983, Barnes \& Hughes 1988, Rincé 1993). The size range of particles ingested by oysters extends from approx. 5 um (100\% retention, Møhlenberg \& Riisgård 1978, Riisgård 1988) to an as yet unknown maximum size. Crassostrea gigas is at least capable of ingesting large numbers of the $250 \times$ $150 \mu \mathrm{m}$ diatom Coscinodiscus perforatus (Cognie et al. 2003). Given that the frontal ciliated surface of a filament is only $40 \mu \mathrm{m}$ in width, it is clear that larger particles must be transported by several filaments simultaneously. Although intuitively, this might seem rather problematic, given the presence of 3 ciliated tracts on each filament and the suggestion of opposite beat directions for each tract (Ribelin \& Collier 1977), it should be kept in mind that the FMT composite cilia are 3 times longer than the FLT cilia (see above), such that larger particles can span adjacent apical fila- ments, and indeed adjacent plicae, and be transported ventrally in a concerted manner. Indeed, video-endoscopic observations show that all large particles, regardless of quality, are transported ventrally on the plicae (Cognie et al. 2003). The observations of the present study are thus consistent with the proposition that the FMT is responsible for the ventralward transport of particles on the oyster gill (Atkins 1937a,b, Ribelin \& Collier 1977). This ventralward transport may represent initial qualitative rejection by the oyster gill for particles smaller than the opening of the principal filament (critical threshold size, CTS). For large particles (>CTS), ventralward transport is indiscriminate, since they cannot enter the dorsally directed tracts of the principal filaments. For such particles, qualitative selection takes place on the labial palps (Cognie et al. 2003). In summary, particles of all sizes may be transported by the FMT of the ordinary filament frontal surface.

\section{Functional correlates: FLT}

While from the foregoing discussion, the role of the FMT now appears evident, that of the FLT is much less obvious. Despite the putative dorsalward beat of these cilia (Atkins 1937a,b, Ribelin \& Collier 1977), dorsalward particle transport on the FLT does not appear to occur naturally. Indeed, Atkins (1937a) describes dorsalward transport on these tracts as 'precarious', being frequently redirected ventrally on the FMT. Moreover, Atkins' (1937a) observation of dorsalward transport on the FLT was only possible in excised gill fragments left for several days. In the video-endoscopic study of Ward et al. (1994) particles were never observed moving dorsally for more than short distances, and all particles on the ordinary filaments were ultimately transported to the ventral particle grooves. These observations can most easily be explained by a dorsalward beat of the FLT cilia, whose chief result is water entrainment rather than particle transport; particles may occasionally be entrained in this current, but this is a minor and very unstable consequence. Nonparticipation of the FLT in particle transport appears most probable, and is supported by the results of the present study, which show that the FMT possesses the most viscous mucus, the type most capable of moving particles ventrally, counter to the prevailing pallial current. We propose therefore that not only are the apical filaments the only active filaments in particle processing by oysters, but also that the FMT of these filaments are the only significant processing sites.

The FLT of the frontal surface of the ordinary filaments nonetheless satisfy the 2 essential conditions for mucociliary transport: abundant ciliation, and relatively abun- 
dant mucocytes. Given the difference in length between the FMT composite cilia and the FLT cilia, and hence the physical separation of their potential treatment surfaces, it is difficult to conceive even the limited role proposed by Ribelin \& Collier (1977): that of the initial reception of particles intercepted by the laterofrontal cirri, and their subsequent transfer to the FMT.

Several examples of abundantly ciliated, mucocyte rich epithelia not involved in particle transport have been found in the bivalve pallial cavity: the ciliated tracts beneath the dorsal fold of the Mytilus edulis labial palp (Beninger et al. 1995), and the abfrontal gill filament surface in the same species (Beninger \& Dufour 2000, Dufour \& Beninger 2001). In both cases, the mucociliary epithelia are vestigial, and appear not to have been subjected to sufficient negative selection to become reduced or disappear. We suggest that the FLT of the frontal surfaces on the ordinary filaments of the oyster constitute another example of such vestigial tracts. Although vestigial with respect to their original anatomical derivation, such surfaces may evolve to assume new functions. In the case of the $M$. edulis gill filament abfrontal surface, it has been argued that the abundant ciliation assists in water pumping; the role, if any, of the abundant mucocytes may be in the reduction of frictional resistance in water passage over the epithelium (Dufour \& Beninger 2001), as has also been suggested for the eulamellibranch gill (Beninger et al. 1997b). Certainly, the dorsalward beat of the FLT cilia on the oyster ordinary filament frontal surfaces could contribute greatly to moving water toward the gill and dorsally, in addition to the activity of the dorsally beating cilia of the principal filaments. The situation from the standpoint of cilia beat, pallial currents, and particle transport would thus be remarkably clear: dorsalward pallial flow is effected by all frontal cilia except the composite cilia of the ordinary filament FMT, which alone are responsible for the ventralward transport of particles on the plicae within a high viscosity mucus, as is the rule in counter-current particle transport on exposed surfaces in bivalves (Beninger \& StJean 1997a).

\section{CONCLUSIONS}

The present study demonstrates that mucocyte mapping can be successfully applied on a very fine scale (mapping within $30 \mu \mathrm{m}$ histologically processed segments, corresponding to $40 \mu \mathrm{m}$ in living tissue), to elucidate surface functional differences. Taken together, the results of the present study and of the previous studies of the 2 heterorhabdic gill types, the heterorhabdic filibranch (Owen \& McCrae 1976, Beninger et al. 1993) and the pseudolamellibranch (Beninger \&
Dufour 1996), show first that the apical filaments greatly dominate in particle processing on the plicae. The major role of the lateral filaments would appear to be the maintenance of the plical form, itself both increasing the filtering surface area and allowing the separation of the dorsal (initial acceptance) and ventral (initial rejection or large particle transport) gill particle tracts, as well as contributing to the dorsalward pallial current via their FLT. Second, within these apical filaments, only the FMT is active in particle processing. Finally, the effectors of the pallial current and of particle transport on the oyster gill are clarified: the dorsalward pallial current is produced not only by the dorsally beating cilia of the principal filaments, but also by those of the FLT of the ordinary filaments, whereas all particle transport on the plicae is effected by the FMT, principally those of the apical filaments.

Acknowledgements. The authors thank Mme O. Aumaille for technical assistance in histology. As the subject of this study has no direct economic or medical impact, it is not possible to acknowledge funding from any of the French funding agencies.

\section{LITERATURE CITED}

Atkins D (1937a) On the ciliary mechanisms and interrelationships of lamellibranchs. Part II. Sorting devices on the gills. Q J Microsc Sci 79:339-373

Atkins D (1937b) On the ciliary mechanisms and interrelationships of lamellibranchs. Part III. Types of lamellibranch gills and their food currents. Q J Microsc Sci 79: $375-421$

Atkins D (1938) On the ciliary mechanisms and interrelationships of lamellibranchs. Part VII. Latero-frontal cilia of the gill filaments and their phylogenic value. Q J Microsc Sci 80:346-430

Barnes RSK, Hughes RN (1988) An introduction to marine ecology, 2nd edn. Blackwell Scientific Publications, Oxford

Beninger PG (2000) Limits and constraints: a comment on promises and methods in recent studies of particle capture mechanisms in bivalves. Limnol Oceanogr 45:1196-1199

Beninger PG, Decottignies P (2005) What makes diatoms attractive for suspensivores? The organic casing and associated organic molecules of Coscinodiscus perforatus are quality cues for the bivalve Pecten maximus. J Plankton Res 27:11-17

Beninger PG, Dufour SC (1996) Mucocyte distribution and relationship to particle transport on the pseudolamellibranch gill of Crassostrea virginica (Bivalvia: Ostreidae). Mar Ecol Prog Ser 137:133-138

Beninger PG, Dufour SC (2000) Evolutionary trajectories of a redundant feature: lessons from bivalve gill abfrontal cilia and mucocyte distributions. Spec Publ Geol Soc Lond 177: $273-278$

Beninger PG, St-Jean SD (1997a) The role of mucus in particle processing by suspension-feeding marine bivalves: unifying principles. Mar Biol 129:389-397

Beninger PG, St-Jean SD (1997b) Particle processing on the labial palps of Mytilus edulis and Placopecten magellanicus (Mollusca: Bivalvia). Mar Ecol Prog Ser 147:117-127

Beninger PG, Veniot A (1999) The oyster proves the rule: 
mechanisms of pseudofaeces transport and rejection on the mantle of Crassostrea virginica and C. gigas. Mar Ecol Prog Ser 190:179-188

Beninger PG, Le Pennec M, Donval A (1991) Mode of particle ingestion in five species of suspension-feeding bivalve molluscs. Mar Biol 108:255-261

Beninger PG, Ward JE, MacDonald BA, Thompson RJ (1992) Gill function and particle transport in Placopecten magellanicus (Mollusca: Bivalvia) as revealed using video endoscopy. Mar Biol 114:281-288

Beninger PG, St-Jean SD, Poussart Y, Ward JE (1993) Gill function and mucocyte distribution in Placopecten magellanicus and Mytilus edulis (Mollusca: Bivalvia): the role of mucus in particle transport. Mar Ecol Prog Ser 98:275-282

Beninger PG, St-Jean SD, Poussart Y (1995) Labial palps of the blue mussel Mytilus edulis (Bivalvia: Mytilidae). Mar Biol 123:293-303

Beninger PG, Lynn JW, Dietz TH, Silverman H (1997a) Mucociliary transport in living tissue: the two-layer model confirmed in the mussel Mytilus edulis L. Biol Bull (Woods Hole) 193:4-7

Beninger PG, Dufour SD, Bourque J (1997b) Particle processing mechanisms of the eulamellibranch bivalves Spisula solidissima and Mya arenaria. Mar Ecol Prog Ser 150:157-169

Beninger PG, Veniot A, Poussart Y (1999) Principles of pseudofeces rejection on the bivalve mantle: integration in particle processing. Mar Ecol Prog Ser 178:259-269

Beninger PG, Dufour SC, Decottignies P, Le Pennec M (2003) Particle processing mechanisms in the archaic, perihydrothermal vent bivalve Bathypecten vulcani, inferred from cilia and mucocyte distributions on the gill. Mar Ecol Prog Ser 246:183-195

Beninger PG, Decottignies P, Rincé Y (2004) Localization of qualitative particle selection sites in the heterorhabdic filibranch Pecten maximus (Bivalvia: Pectinidae). Mar Ecol Prog Ser 275:163-173

Cognie B (2001) Alimentation de l'huître Crassostrea gigas (Thunberg): étude des mécanismes de sélection des particules et des processus rétroactifs entre le bivalve et les microalgues. PhD thesis, University of Nantes

Cognie B, Barillé L, Massé G, Beninger PG (2003) Selection and processing of large suspended algae in the oyster Crassostrea gigas. Mar Ecol Prog Ser 250:145-152

Dufour SC, Beninger PG (2001) A functional interpretation of cilia and mucocyte distributions on the abfrontal surface of bivalve gills. Mar Biol 138:295-309

Grenon JF, Walker G (1978) The histology and histochemistry of the pedal glandular system of two limpets, Patella vulgata and Acmaea tessulata (Gastropoda: Prosobranchia). J Mar Biol Assoc UK 58:803

Lakshminarayana JSS (1983) Phytoplankton of the Quoddy region. Can Spec Publ Fish Aquat Sci 64:176-192

Levinton JS (1982) Marine ecology. Prentice-Hall, Englewood Cliffs, NJ

Editorial responsibility: Otto Kinne (Editor-in-Chief), Oldendorf/Luhe, Germany
Møhlenberg F, Riisgård HU (1978) Efficiency of particle retention in 13 species of suspension feeding bivalves. Ophelia 17:239-246

Nielsen NF, Larsen PS, Riisgård HU, Jørgensen CB (1993) Fluid motion and particle retention in the gill of Mytilus edulis: video recordings and numerical modelling. Mar Biol 116:61-71

Owen G, McCrae JM (1976) Further studies on the laterofrontal tracts of bivalves. Proc R Soc Lond B 194: $527-544$

Ribelin BW, Collier A (1977) Studies on the gill ciliation of the American oyster Crassostrea virginica (Gmelin). J Morphol 151:439-450

Riisgård HU (1988) Efficiency of particle retention and filtration rate in 6 species of northeast American bivalves. Limnol Oceanogr 45:1192-1195

Riisgård HU, Larsen PS (2000) Comparative ecophysiology of active zoobenthic filter feeding, essence of current knowledge. J Sea Res 44:169-193

Riisgård HU, Larsen PS (2001) Minireview: Ciliary filter feeding and bio-fluid dynamics - present understanding and unsolved problems. Limnol Oceanogr 46:882-891

Riisgård HU, Larsen PS, Nielsen HF (1996) Particle capture in the mussel Mytilus edulis: the role of the latero-frontal cirri. Mar Biol 127:259-266

Rincé Y (1993) Les diatomées marines de la région de BasseLoire: inventaire, distribution spatio-temporelle et devenir expérimental des peuplements naturels d'écosystèmes ostréicoles. PhD thesis, University of Nantes

Ropert M, Goulletquer P (2000) Comparative physiological energetics of two suspension feeders: polychaete annelid Lanice conchilega (Pallas 1766) and Pacific cupped oyster Crassostrea gigas (Thunberg 1795). Aquaculture 181: 171-189

Silverman H, Lynn JW, Beninger PG, Dietz TH (1999) The role of latero-frontal cirri in particle capture by the gills of Mytilus edulis. Biol Bull (Woods Hole) 197:368-376

Silverman H, Lynn JW, Dietz TH (1996) Particle capture by the gills of Dreissena polymorpha: structure and function of latero-frontal cirri. Biol Bull 191:42-54

Veniot A (2003) Etude de la structure et de l'ultrastructure des cils composites chez quatre espèces de bivalves. MSc thesis, University of Moncton, NB

Ward JE, MacDonald BA, Thompson RJ, Beninger PG (1993) Mechanisms of suspension feeding in bivalves: resolution of current controversies by means of endoscopy. Limnol Oceanogr 38:265-272

Ward JE, Newell RIE, Thompson RJ, MacDonald BA (1994) In vivo studies of suspension-feeding processes in the eastern oyster, Crassostrea virginica (Gmelin). Biol Bull 186: $221-240$

Ward JE, Levinton JS, Shumway SE, Succi T (1998) Particle sorting in bivalves: in vivo determination of the pallial organs of selection. Mar Biol 131:283-292

Submitted: November 29, 2004; Accepted: February 23, 2005 Proofs received from author(s): June 6, 2005 